\title{
Pengaruh Bauran Pemasaran Syariah terhadap Keputusan Konsumen Membeli Produk pada Sentra Oleh-Oleh Makanan di Pasar Wisata Pekanbaru
}

\author{
Lisa Nurjanah, Julina, Sitti Rahmah. \\ ${ }^{1}$ Universitas Islam Negeri Sultan Syarif Kasim Riau \\ 2Program Studi Ekonomi Syariah \\ E-mail: Lisanurjanahcis17@gmail.com,julina@uin-suska.ac.id, sitirahmah@uin-suska.ac.id
}

\begin{abstract}
Abstrak
Penelitian ini dilatarbelakangi untuk mengetahui adakah pengaruh secara parsial dan simultan antara variabel produk (product), persepsi harga (price perception), tempat (place), promosi (promotion), SDM/Orang (people), proses (process), bukti fisik (physical evidence), sabar (patience), dan janji (promise), terhadap keputusan konsumen membeli produk pada sentra oleholeh makanan di Pasar Wisata Pekanbaru. Jenis penelitian yang digunakan adalah penelitian lapangan (field research) dengan metode penelitian kuantitatif. Populasi dan sampel dalam penelitian ini adalah konsumen yang membeli produk pada sentra oleh-oleh makanan di Pasar Wisata Pekanbaru sejumlah 96 orang. Teknik pengumpulan data dalam penelitian ini melalui observasi, wawancara, kuesioner, dan dokumentasi, dan lokasi penelitian berada di Pekanbaru, sedangkan dalam pengolahan data menggunakan bantuan program SPSS versi 24.0 Berdasarkan hasil penelitian diperoleh hasil secara keseluruhan variabel product, price perception, place, promotion, people, process, physical evidence, patience, dan promise berpengaruh secara parsial dan simultan terhadap keputusan konsumen membeli produk pada sentra oleh-oleh makanan di Pasar Wisata Pekanbaru.
\end{abstract}

Kata Kunci: Bauran, Pemasaran, Syari'ah, Membeli Produk.

\begin{abstract}
This research is motivated to know is there any effect partially and simultaneously between the variables of the product (product), perception of price (price perception), where (place), promotion (promotion), HR / People (people), process (process), physical evidence (physical evidence), patience (patience), and promise (promise), towards consumer decisions to buy products at the food souvenir center at Pasar Wisata Pekanbaru. The type of research used is field research with quantitative research methods. The population and sample in this study were 96 consumers who bought products at the food souvenir center at the Pekanbaru Tourism Market. Data collection techniques in this research through observation,
\end{abstract}


interviews, questionnaires, and documentation and research sites located in Pekanbaru, whereas in data processing using SPSS version 24.0 Based ha seals the research results as a whole variable product, price perception, place, promotion, people, process, physical evidence, patience , and promise an effect of partial and simultaneously to consumer decisions to buy products at the center of souvenirs food in Pekanbaru Travel Market.

Keywords : Bauran, Pemasaran, Syari'ah, Membeli Produk.

\section{Pendahuluan}

Banyak usaha yang dilakukan manusia dalam pemenuhan kebutuhan hidupnya. Salah satunya adalah berdagang. Dalam membuat rencana bisnis. Bauran pemasaran (Marketing Mix) merupakan kombinasi dari variabel atau kegiatan yang merupakan inti dari sistem pemasaran. Hal ini berarti, bauran pemasaran sebagai kumpulan-kumpulan variabel-variabel yang dapat digunakan perusahaan untuk mempengaruhi tanggapan konsumen. Sehingga dengan adanya variabel-variabel yang digunakan perusahaan maka akan menciptakan suatu kombinasi yang memberikan hasil maksimal. ${ }^{1}$

Bauran pemasaran terdiri dari semua hal yang dapat dilakukan perusahaan untuk mempengaruhi permintaan produknya. Berbagai kemungkinan ini dapat dikelompokkan menjadi sembilan variable yang disebut dengan "9P" product (produk), price perception ( persepsi harga), place (tempat), dan promotion (promosi), people (orang), process (proses), physical evidence (bukti fisik), patience (sabar), dan terakhir promise (janji). Dengan kata lain, antara product dan price adalah komponen dari tawaran (offers), sedangkan place dan promotion adalah komponen dari akses (acces). Karena itu, marketing mix yang dimaksud adalah bagaimana mengintegrasikan tawaran dari perusahaan (company`s acces). ${ }^{2}$

Dalam pandangan Islam pasar merupakan wahana atau tempat transaksi ekonomi yang ideal, tetapi memiliki berbgai kelemahan yang tidak cukup memadai percapaian tujuan ekonomi yang Islami. Pasar Wisata menjadi salah satu icon bagi masyarakat Riau khususnya Pekanbaru yang sudah berdiri lama dan fenomena lain yakni dalam permasalahan ini adalah lahan parkir yang terbatas, fasilitas ibadah yang kurang memadai, tempat yang lumayan panas, dan kurangnya minat pembeli untuk berbelanja di Pasar Wisata Pekanbaru sehingga menyebabkan berkurangnya omset penjualan pedagang di Pasar Wisata Pekanbaru.

1 Zainal Abidin Mohd, Pengurusan pemasaran, (Kuala Lumpur: Dewan Bahasa, 1992) hlm. 240

${ }^{2}$ Hermawan Kertajaya \& Muhammad Syakir Sula, Syariah Marketing, (Bandung: PT. Mizan, 2006) hlm. 177 
Adapun rumusan masalah dalam penelitian ini adalah : a) Bagaimana pengaruh bauran pemasaran syariah variabel produk (product) terhadap keputusan konsumen membeli produk pada sentra oleh-oleh makanan di Pasar Wisata Pekanbaru? b) Bagaimana pengaruh bauran pemasaran syariah variabel persepsi harga (price perception) terhadap keputusan konsumen membeli produk pada sentra oleh-oleh makanan di Pasar Wisata Pekanbaru? c) Bagaimana pengaruh bauran pemasaran syariah variabel tempat (place) terhadap keputusan konsumen membeli produk pada sentra oleh-oleh makanan di Pasar Wisata Pekanbaru? d) Bagaimana pengaruh bauran pemasaran syariah variabel promosi (promotion) terhadap keputusan konsumen membeli produk pada sentra oleh-oleh makanan di Pasar Wisata Pekanbaru? e) Bagaimana pengaruh bauran pemasaran syariah variabel sumber daya manusia/sdm (people) terhadap keputusan konsumen membeli produk pada sentra oleh-oleh makanan di Pasar Wisata Pekanbaru? f) Bagaimana pengaruh bauran pemasaran syariah variabel proses (process) terhadap keputusan konsumen membeli produk pada sentra oleh-oleh makanan di Pasar Wisata Pekanbaru? g) Bagaimana pengaruh bauran pemasaran syariah variabel bukti fisik (physical evidence) terhadap keputusan konsumen membeli produk pada sentra oleh-oleh makanan di Pasar Wisata Pekanbaru? h) Bagaimana pengaruh bauran pemasaran syariah variabel bukti sabar (patience) terhadap keputusan konsumen membeli produk pada sentra oleh-oleh makanan di Pasar Wisata Pekanbaru? i) Bagaimana pengaruh bauran pemasaran syariah variabel janji (promise) terhadap keputusan konsumen membeli produk pada sentra oleh-oleh makanan di Pasar Wisata Pekanbaru? j) Bagaimana pengaruh bauran pemasaran syariah yang terdiri dari 9p (product, price, place, promotion, people, process, physical evidence, patience, promise) terhadap keputusan konsumen membeli produk pada sentra oleh-oleh makanan di Pasar Wisata Pekanbaru?

Sedangkan tujuan dari penelitian yang penulis lakukan adalah sebagai berikut: a) Untuk mengetahui pengaruh bauran pemasaran syariah variabel produk (product) terhadap keputusan konsumen membeli produk pada sentra oleh-oleh makanan di Pasar Wisata Pekanbaru. b) Untuk mengetahui pengaruh bauran pemasaran syariah variabel persepsi harga (price perception) terhadap keputusan konsumen membeli produk pada sentra oleh-oleh makanan di Pasar Wisata Pekanbaru. c) Untuk mengetahui pengaruh bauran pemasaran syariah variabel tempat (place) terhadap keputusan konsumen membeli produk pada sentra oleh-oleh makanan di Pasar Wisata Pekanbaru. d) Untuk mengetahui pengaruh bauran pemasaran syariah variabel promosi (promotion) terhadap keputusan konsumen membeli produk pada sentra oleh-oleh makanan di Pasar Wisata Pekanbaru. 
e) Untuk mengetahui pengaruh bauran pemasaran syariah variabel sumber daya manusia/sdm (people) terhadap keputusan konsumen membeli produk pada sentra oleh-oleh makanan di Pasar Wisata Pekanbaru. f) Untuk mengetahui pengaruh bauran pemasaran syariah variabel proses (process) terhadap keputusan konsumen membeli produk pada sentra oleh-oleh makanan di Pasar Wisata Pekanbaru. g) Untuk mengetahui pengaruh bauran pemasaran syariah variabel bukti fisik (physical evidence) terhadap keputusan konsumen membeli produk pada sentra oleh-oleh makanan di Pasar Wisata Pekanbaru. h) Untuk mengetahui pengaruh bauran pemasaran syariah variabel sabar (patience) terhadap keputusan konsumen membeli produk pada sentra oleh-oleh makanan di Pasar Wisata Pekanbaru. i) Untuk mengetahui pengaruh bauran pemasaran syariah variabel janji (promise) terhadap keputusan konsumen membeli produk pada sentra oleh-oleh makanan di Pasar Wisata Pekanbaru. j) Untuk mengetahui pengaruh bauran pemasaran syariah yang terdiri dari 9p (product, price, place, promotion, people, process, physical evidence. patience, promise) terhadap keputusan keputusan konsumen membeli produk pada sentra oleh-oleh makanan di Pasar Wisata Pekanbaru.

Tujuan dari pemasaran atau bauran pemasaran itu sendiri yakni untuk memahami keinginan dan kebutuhan pelanggan agar produk atau jasa yang ditawarkan oleh produsen dapat cocok dihati konsumen maupun pelanggan, dengan kata lain ketika seorang pemasar meningkatkan Bauran Pemasaran Syariah dalam melakukan kegiatan pemasaran maka keputusan membeli produk pada sentra oleh-oleh makanan di Pasar Wisata Pekanbaru akan mengalami peningkatan dan sebaliknya, apabila seorang pemasar menurunkan strategi pemasaran maka akan mengalami penurunan terhadap keputusan membeli produk pada sentra oleh-oleh makanan di Pasar Wisata Pekanbaru.

Berdasarkan penelitian terdahulu menurut Istianah, Kholil Nawawi dan Syarifah Gustiawati Jurnal Ekonomi Syariah Volume 5 Nomor 1 Tahun 2018, di dalam penelitiannya Analisis Sharia Marketing Mix Terhadap Kepercayaan Pelanggan dan Keputuasan Pembelian pada Online Shop Tiws.id meneliti variabel Bauran Pemasaran syariah dalam penelitian yang dilakukannya bahwa Sharia marketing mix berpengaruh positif dan signifikan terhadap kepercayaan pelanggan, Sharia marketing mix berpengaruh positif dan signifikan antara terhadap keputusan pembelian pada online shop Tiws.id. ${ }^{3}$

${ }^{3}$ Istianah, Kholil Nawawi dan Syarifah Gustiawati, Analisis Sharia Marketing Mix Terhadap Kepercayaan Pelanggan dan Keputuasan Pembelian pada Online Shop Tiws.id, Jurnal Ekonomi Syariah Volume 5 Nomor 1 Tahun 2018 
Penelitian lainnya oleh Angelina Rares, Rotinsulu Jopie Jorie (2015), (The Effect of The Price, Promotion, Location, Brand Image And Quality Products Towards The Purchase Decision Of Consumers At Bengkel Gaoel Store Manado Town Square) Pengaruh Harga, Promosi, Lokasi, Citra Merek Dan Kualitas Produk Terhadap Keputusan Pembelian Konsumen di Toko Bengkel Gaoel Manado Town Square. Hasil penelitian menunjukkan secara simultan harga, promosi, lokasi, citra merek dan kualitas produk berpengaruh signifikan terhadap keputusan pembelian. Secara parsial harga dan kualitas produk berpengaruh signifikan terhadap keputusan pembelian sementara promosi, lokasi dan citra merek tidak berpengaruh signifkan terhadap keputusan pembelian. ${ }^{4}$

Berdasarkan hasil penelitian terdahulu di atas, penulis mendapati memang banyak penelitian yang berkaitan dengan pengaruh marketing mix terhadap keputusan pembelian, minat beli, loyalitas pelanggan, dan kepuasan pelanggan. Namun dalam penelitian ini, peneliti mereplikasi ulang mengenai bauran pemasaran syariah terhadap keputusan konsumen membeli produk pada sentra oleh-oleh makanan di Pasar Wisata Pekanbaru dengan menggunakan variabel pemasaran dengan konsep pemasaran syariah diambil dari penelitian terdahulu yakni Samir Abuznaid5, dengan variabel: product (produk), price (harga), promotion (promosi), place (tempat), physical evidence (bukti fisik), process (proses), dan people (orang), promise (janji), dan patience (sabar). Serta membahas tentang pemasaran internasional dalam bauran pemasaran Islam yang berbasis Islami, sedangkan dalam penelitian ini focus terhadap produk-produk umum yang berkaitan dengan permasalahan marketing mix dan keputusan pembelian di Pasar Wisata Pekanbaru.

\section{Metode}

Penelitian ini termasuk dalam jenis penelitian lapangan (field research). Analisa data yang digunakan dalam penelitian ini adalah pendekatan kuantitatif. 6 Penelitian ini dilakukan di Pasar Wisata Pekanbaru yang berlokasi di jalan Saleh Abbas, Kelurahan Kampung dalam, Kecamatan Senapelan, Kota Pekanbaru. Waktu penelitian ini dilakukan mulai bulan Agustus 2020, dan subjek dalam penelitian ini yaitu konsumen yang membeli produk pada sentra oleh-oleh makanan di Pasar Wisata Pekanbaru. Populasi dalam penelitian ini sebanyak 96 orang.

\footnotetext{
${ }^{4}$ Angelina Rares, Rotinsulu Jopie Jorie , "The Effect Of The Price, Promotion, Location, Brand Image And Quality Products Towards The Purchase Decision Of Consumers At Bengkel Gaoel Store Manado Town Square “, Jurnal EMBA,Vol.3 No.2 Juni 2015 ISSN 2303-1174

${ }^{5}$ Samir Abuznaid, Islamic Marketing : Addessing The Muslim Market, Journal AnNajah Univ.J.Res (humanities), Vol. 26, 2012.

${ }^{6}$ Suwartono, Dasar-dasar Metodologi Penelitian, (Yogyakarta : Andi, 2014), hlm. 30
} 
Adapun jenis-jenis dan sumber data yang penulis gunakan dalam penelitian ini yaitu: (1) Data Primer, yaitu data dari sumber langsung yang penulis dapatkan dari responden di lapangan yakni konsumen yang membeli produk pada sentra oleh-oleh makanan di Pasar Wisata Pekanbaru. ${ }^{7}$ (2) Data Sekunder, yaitu data yang penulis peroleh dari pihak-pihak yang terkait, serta buku-buku, jurnal atau kitab-kitab perpustakaan yang dapat membantu penelitian ini guna melengkapi data-data. Teknik pengumpulan dan pengolahan data merupakan pengumpulan data yaitu pencatatan peristiwa/hal-hal atau keterangan-keterangan sebagian/seluruh elemen populasi yang akan mendukung penelitian. ${ }^{8}$ Adapun teknik pengumpulan dan pengolahan data dalam penelitian ini yaitu menggunakan: wawancara, observasi, dokumentasi, angket/kuesioner, dan studi pustaka. Adapun dalam teknik analisa data menggunakan regresi linier berganda.

\section{Hasil dan Pembahasan}

Tabel. 1 Karakteristik Responden Berdasarkan Jenis Kelamin

\begin{tabular}{|c|l|c|c|}
\hline No. & Jenis Kelamin & Frekuensi & Persentase \\
\hline 1 & Laki-Laki & 25 & $26 \%$ \\
\hline 2 & Perempuan & 71 & $74 \%$ \\
\hline \multicolumn{2}{|c|}{ Jumlah } & $\mathbf{9 6}$ & $\mathbf{1 0 0 \%}$ \\
\hline
\end{tabular}

Berdasarkan Tabel.1 diketahui bahwa responden dengan jenis kelamin laki-laki berjumlah 25 orang. Sedangkan responden dengan jenis kelamin perempuan berjumlah 71 orang. Hal ini menunjukkan bahwa dalam penelitian ini responden dengan jenis kelamin perempuan yang mendominasi menjadi pembeli pada produk oleh-oleh makanan di Pasar Wisata Pekanbaru.

Tabel. 2 Karakteristik Responden Berdasarkan Usia

\begin{tabular}{|c|c|c|c|}
\hline No. & Usia & Frekuensi & Persentase \\
\hline 1 & $18-25$ tahun & 29 & $30,2 \%$ \\
\hline 2 & $26-35$ tahun & 35 & $36,4 \%$ \\
\hline 3 & $36-45$ tahun & 26 & $27,0 \%$ \\
\hline 4 & 45 Tahun Keatas & 6 & $6,25 \%$ \\
\hline \multicolumn{2}{|r|}{} \\
\cline { 2 - 4 }
\end{tabular}

7 Iqbal Hasan, Analisis Data Penelitian Dengan Statistik, (Jakarta : Bumi Aksara, 2004), hlm. 19

${ }^{8}$ Iqbal Hasan, Pokok-pokok Materi Metodologi Penelitian dan Aplikasinya, (Jakarta: Ghalia Indonesia, 2002), hlm. 83 
Berdasarkan Tabel.2 diketahui bahwa usia responden 18-25 tahun berjumlah 29 orang, responden dengan usia 26-35 tahun berjumlah 35 orang, responden dengan usia 36-45 tahun berjumlah 26 orang, dan responden dengan usia 45 tahun ke atas berjumlah 6 orang. Hal ini menunjukkan bahwa dalam penelitian rentang usia 26-35 tahun yang mendominasi menjadi pembeli pada produk oleh-oleh makanan di Pasar Wisata Pekanbaru.

Tabel. 3 Karakteristik Responden Berdasarkan Tingkat Pendidikan Terakhir

\begin{tabular}{|c|c|c|c|}
\hline No. & Tingkat Pendidikan & Frekuensi & Persentase \\
\hline 1 & SMA/MA & 10 & $10,4 \%$ \\
\hline 2 & S1 & 49 & $51,0 \%$ \\
\hline 3 & S2 & 22 & $22,9 \%$ \\
\hline 4 & S3 & 15 & $15,6 \%$ \\
\hline & Jumlah & 96 & $100 \%$ \\
\hline
\end{tabular}

Berdasarkan Tabel.3, menunjukkan bahwa responden dengan pendidikan terakhir SMA/MA berjumlah 10 orang, responden dengan pendidikan terakhir S1 berjumlah 49 orang, responden dengan pendidikan terakhir S2 berjumlah 22 orang, dan responden dengan pendidikan terakhir S3 berjumlah 15 orang. Hal ini menunjukkan bahwa dalam penelitian ini responden dengan pendidikan terakhir S1 yang mendominasi menjadi menjadi pembeli pada produk oleh-oleh makanan di Pasar Wisata Pekanbaru.

Tabel. 4 Karakteristik Responden Berdasarkan Alamat

\begin{tabular}{|c|c|c|c|}
\hline No. & $\begin{array}{c}\text { Alamat (Kecamatan di Kota } \\
\text { Pekanbaru) }\end{array}$ & Frekuensi & Persentase \\
\hline 1 & Bukit Raya & 8 & $8,3 \%$ \\
\hline 2 & Tenayan Raya & 6 & $6,25 \%$ \\
\hline 3 & Tampan & 12 & $12,5 \%$ \\
\hline 4 & Rumbai & 6 & $6,25 \%$ \\
\hline 5 & Rumbai Pesisir & 4 & $4,1 \%$ \\
\hline 6 & Payung Sekaki & 3 & $3,1 \%$ \\
\hline 7 & Marpoyan Damai & 10 & $5,2 \%$ \\
\hline 8 & Sukajadi & 20 & $10,4 \%$ \\
\hline 9 & Senapelan & 10 & $10,4 \%$ \\
\hline 10 & Sail & 5 & $5,2 \%$ \\
\hline 11 & Lima Puluh & $\mathbf{7}$ & $7,2 \%$ \\
\hline 12 & Pekanbaru Kota & $\mathbf{9 6}$ & $\mathbf{1 0 0} \%$ \\
\hline
\end{tabular}

Berdasarkan Tabel.4, menunjukkan bahwa responden yang berlamat di Bukit Raya berjumlah 8 orang, responden yang beralamat di Tenanan Raya 
berjumlah 6 orang, responden yang beralamat di Tampan berjumlah 12 orang, responden yang beralamat di Rumbai berjumlah 6 orang, responden yang beralamat di Rumbai Pesisir berjumlah 4 orang, responden yang beralamat di Payung Sekaki berjumlah 3 orang, responden yang beralamat di Marpoyan Damai berjumlah 5 orang, responden yang beralamat di Sukajadi berjumlah 10 orang, responden yang beralamat di Senapelan berjumlah 20 orang, responden yang beralamat di Sail sebanyak 10 orang, responden yang beralamat di Lima Puluh berjumlah 5 orang dan responden yang beralamat di Pekanbaru Kota berjumlah 7 orang.

Tabel. 5 Karakteristik Responden Berdasarkan Jenis Pekerjaan

\begin{tabular}{|c|c|c|c|}
\hline No. & Jenis Pekerjaan & Frekuensi & Persentase \\
\hline 1 & Mahasiswa & 30 & $31,25 \%$ \\
\hline 2 & Pegawai Negeri & 10 & $10,4 \%$ \\
\hline 3 & Pegawai Swasta & 15 & $15,6 \%$ \\
\hline 4 & Wiraswasta & 6 & $6,25 \%$ \\
\hline 5 & Dosen/Guru PNS & 10 & $10,4 \%$ \\
\hline 6 & Dosen/Guru Swasta & 5 & $5,2 \%$ \\
\hline 7 & Ibu Rumah Tangga & 15 & $15,6 \%$ \\
\hline 8 & Lain-lain & 5 & $5,2 \%$ \\
\hline \multicolumn{2}{|c|}{ 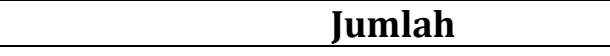 } & 96 & $100 \%$ \\
\hline
\end{tabular}

Berdasarkan Tabel IV.5, dapat dilihat bahwa responden dengan status mahasiswa lebih mendominasi dalam penelitian ini yaitu sebanyak 30 orang dengan persentase $30 \%$.

Tabel. 6 Karakteristik Responden Berdasarkan Total Pendapatan Perbulan

\begin{tabular}{|c|c|c|c|}
\hline No. & Total Pendapatan Perbulan & Frekuensi & Persentase \\
\hline 1 & < Rp. 1.500 .000 & 40 & $41,6 \%$ \\
\hline 2 & Rp. 1.500 .000 - Rp. 2.500 .000 & 15 & $15,6 \%$ \\
\hline 3 & Rp. 2.500.000 - Rp. 3.500.000 & 5 & $5,2 \%$ \\
\hline 4 & Rp. 3.500.000 - Rp. 4.500.000 & 6 & $6,25 \%$ \\
\hline 5 & Rp. 4.500.000 - Rp. 5.500.000 & 5 & $5,2 \%$ \\
\hline 6 & Rp. 5.500.000 - Rp. 6.500.000 & 4 & $4,1 \%$ \\
\hline 7 & Rp. 6.500.000 - Rp. 7.500.000 & 2 & $2,0 \%$ \\
\hline 8 & Rp.7.500.000 sd Rp. 8.500.000 & 2 & $2,0 \%$ \\
\hline 9 & Rp. 8.500.000 sd Rp. 9.500.000 & 2 & $2,0 \%$ \\
\hline 10 & Belum Berpenghasilan/ Belum Bekerja & 15 & $15,6 \%$ \\
\hline \multicolumn{2}{|c|}{} & $\mathbf{9 6}$ & $\mathbf{1 0 0 \%}$ \\
\hline
\end{tabular}

Berdasarkan Tabel IV.6 menunjukkan bahwa responden dengan total pendapatan <Rp.1.500.000 lebih mendominasi dalam penelitian ini yaitu sebanyak 40 responden dengan persentase $40 \%$.

Tabel. 7 Uji Validitas Variabel Independen Produk (Product)

\begin{tabular}{|c|c|c|c|}
\hline Pernyataan & r Hitung & r Tabel & Keterangan \\
\hline P1 & 0,212 & 0,209 & Valid \\
\hline P2 & 0,414 & 0,209 & Valid \\
\hline
\end{tabular}




\begin{tabular}{|c|c|c|c|}
\hline P3 & 0,466 & 0,209 & Valid \\
\hline P4 & 0,424 & 0,209 & Valid \\
\hline P5 & 0,439 & 0,209 & Valid \\
\hline P6 & 0,678 & 0,209 & Valid \\
\hline P7 & 0,617 & 0,209 & Valid \\
\hline P8 & 0,662 & 0,209 & Valid \\
\hline P9 & 0,547 & 0,209 & Valid \\
\hline P10 & 0,516 & 0,209 & Valid \\
\hline
\end{tabular}

Berdasarkan Tabel.7 menunjukkan bahwa nilai $\mathrm{r}$ tabel Product Moment pada signifikansi 0,05 dan 2 sisi dengan nilai $\mathrm{N}=96, \mathrm{df}=96-2=94$ nilai yang didapat adalah 0,209 . Sedangkan nilai $r$ hitung diketahui bahwa $r$ hitung $\geq \mathrm{r}$ tabel, maka dapat disimpulkan bahwa semua butir pernyataan untuk variabel produk (product) adalah valid, dan tidak terdapat pernyataan yang tidak valid dalam semua butir pernyataan variabel produk (product) sehingga dapat diolah kepengujian selanjutnya.

Tabel. 8 Uji Validitas Variabel Independen Persepsi Harga (Price Perception)

\begin{tabular}{|c|c|c|c|}
\hline Pernyataan & r Hitung & r Tabel & Keterangan \\
\hline PH1 & 0,407 & 0,209 & Valid \\
\hline PH2 & 0,309 & 0,209 & Valid \\
\hline PH3 & 0,373 & 0,209 & Valid \\
\hline PH4 & 0,500 & 0,209 & Valid \\
\hline PH5 & 0,448 & 0,209 & Valid \\
\hline PH6 & 0,584 & 0,209 & Valid \\
\hline PH7 & 0,287 & 0,209 & Valid \\
\hline PH8 & 0,646 & 0,209 & Valid \\
\hline
\end{tabular}

Berdasarkan Tabel.8 menunjukkan bahwa nilai $r$ tabel Product Moment pada signifikansi 0,05 dan 2 sisi dengan nilai $\mathrm{N}=96, \mathrm{df}=96-2=94$ nilai yang didapat adalah 0,209 . Sedangkan nilai $r$ hitung diketahui bahwa $r$ hitung $\geq \mathrm{r}$ tabel, maka dapat disimpulkan bahwa semua butir pernyataan untuk variabel persepsi harga (price perception) adalah valid, dan tidak terdapat pernyataan yang tidak valid dalam semua butir pernyataan variabel persepsi harga (price perception) sehingga dapat diolah kepengujian selanjutnya.

Tabel. 9 Uji Validitas Variabel Independen Tempat (Place)

\begin{tabular}{|c|c|c|c|}
\hline Pernyataan & r Hitung & r Tabel & Keterangan \\
\hline T1 & 0,516 & 0,209 & Valid \\
\hline T2 & 0,375 & 0,209 & Valid \\
\hline T3 & 0,502 & 0,209 & Valid \\
\hline T4 & 0,560 & 0,209 & Valid \\
\hline T5 & 0,474 & 0,209 & Valid \\
\hline T6 & 0,423 & 0,209 & Valid \\
\hline T7 & 0,432 & 0,209 & Valid \\
\hline T8 & 0,431 & 0,209 & Valid \\
\hline
\end{tabular}


Berdasarkan Tabel.9 menunjukkan bahwa nilai $r$ tabel Product Moment pada signifikansi 0,05 dan 2 sisi dengan nilai $\mathrm{N}=96, \mathrm{df}=96-2=94$ nilai yang didapat adalah 0,209 . Sedangkan nilai $r$ hitung diketahui bahwa $r$ hitung $\geq \mathrm{r}$ tabel, maka dapat disimpulkan bahwa semua butir pernyataan untuk variabel tempat (place) adalah valid, dan tidak terdapat pernyataan yang tidak valid dalam semua butir pernyataan variabel tempat (place) sehingga dapat diolah kepengujian selanjutnya.

Tabel. 10 Uji Validitas Variabel Independen Promosi (Promotion)

\begin{tabular}{|c|c|c|c|}
\hline Pernyataan & r Hitung & r Tabel & Keterangan \\
\hline PROM1 & 0,235 & 0,209 & Valid \\
\hline PROM2 & 0,475 & 0,209 & Valid \\
\hline PROM3 & 0,234 & 0,209 & Valid \\
\hline PROM4 & 0,330 & 0,209 & Valid \\
\hline PROM5 & 0,539 & 0,209 & Valid \\
\hline PROM6 & 0,681 & 0,209 & Valid \\
\hline PROM7 & 0,494 & 0,209 & Valid \\
\hline PROM8 & 0,475 & 0,209 & Valid \\
\hline PROM9 & 0,348 & 0,209 & Valid \\
\hline PROM10 & 0,305 & 0,209 & Valid \\
\hline
\end{tabular}

Berdasarkan Tabel.10 menunjukkan bahwa nilai $\mathrm{r}$ tabel Product Moment pada signifikansi 0,05 dan 2 sisi dengan nilai $\mathrm{N}=96, \mathrm{df}=96-2=94$ nilai yang didapat adalah 0,209 . Sedangkan nilai $r$ hitung diketahui bahwa $r$ hitung $\geq \mathrm{r}$ tabel, maka dapat disimpulkan bahwa semua butir pernyataan untuk variabel promosi (promotion) adalah valid, dan tidak terdapat pernyataan yang tidak valid dalam semua butir pernyataan variabel promosi (promotion) sehingga dapat diolah kepengujian selanjutnya.

Tabel. 11 Uji Validitas Variabel Independen Sumber Daya Manusia/SDM (People)

\begin{tabular}{|c|c|c|c|}
\hline Pernyataan & r Hitung & r Tabel & Keterangan \\
\hline 01 & 0,404 & 0,209 & Valid \\
\hline 02 & 0,519 & 0,209 & Valid \\
\hline 03 & 0,485 & 0,209 & Valid \\
\hline 04 & 0,424 & 0,209 & Valid \\
\hline 05 & 0,544 & 0,209 & Valid \\
\hline 06 & 0,354 & 0,209 & Valid \\
\hline
\end{tabular}

Berdasarkan Tabel.11 menunjukkan bahwa nilai $r$ tabel Product Moment pada signifikansi 0,05 dan 2 sisi dengan nilai $\mathrm{N}=96, \mathrm{df}=96-2=94$ nilai yang didapat adalah 0,209 . Sedangkan nilai $r$ hitung diketahui bahwa $r$ hitung $\geq \mathrm{r}$ tabel, maka dapat disimpulkan bahwa semua butir pernyataan untuk variabel sumber daya manusia/sdm (people) adalah valid, dan tidak terdapat pernyataan yang tidak valid dalam semua butir pernyataan variabel 
sumber daya manusia/sdm (people) sehingga dapat diolah kepengujian selanjutnya.

Tabel. 12 Uji Validitas Variabel Independen Proses (Process)

\begin{tabular}{|c|c|c|c|}
\hline Pernyataan & r Hitung & r Tabel & Keterangan \\
\hline PROS1 & 0,466 & 0,209 & Valid \\
\hline PROS2 & 0,607 & 0,209 & Valid \\
\hline PROS3 & 0,443 & 0,209 & Valid \\
\hline PROS4 & 0,510 & 0,209 & Valid \\
\hline
\end{tabular}

Berdasarkan Tabel.12 menunjukkan bahwa nilai $\mathrm{r}$ tabel Product Moment pada signifikansi 0,05 dan 2 sisi dengan nilai $\mathrm{N}=96, \mathrm{df}=96-2=94$ nilai yang didapat adalah 0,209 . Sedangkan nilai $r$ hitung diketahui bahwa $r$ hitung $\geq \mathrm{r}$ tabel, maka dapat disimpulkan bahwa semua butir pernyataan untuk variabel proses (process) adalah valid, dan tidak terdapat pernyataan yang tidak valid dalam semua butir pernyataan variabel proses (process) sehingga dapat diolah kepengujian selanjutnya.

Tabel. 13 Uji Validitas Variabel Independen Bukti Fisik (Physical Evidence)

\begin{tabular}{|c|c|c|c|}
\hline Pernyataan & r Hitung & r Tabel & Keterangan \\
\hline BF1 & 0,344 & 0,209 & Valid \\
\hline BF2 & 0,484 & 0,209 & Valid \\
\hline BF3 & 0,420 & 0,209 & Valid \\
\hline BF4 & 0,671 & 0,209 & Valid \\
\hline
\end{tabular}

Berdasarkan Tabel.13 menunjukkan bahwa nilai $\mathrm{r}$ tabel Product Moment pada signifikansi 0,05 dan 2 sisi dengan nilai $\mathrm{N}=96, \mathrm{df}=96-2=94$ nilai yang didapat adalah 0,209 . Sedangkan nilai $r$ hitung diketahui bahwa $r$ hitung $\geq \mathrm{r}$ tabel, maka dapat disimpulkan bahwa semua butir pernyataan untuk variabel bukti fisik (physical evidence) adalah valid, dan tidak terdapat pernyataan yang tidak valid dalam semua butir pernyataan variabel bukti fisik (physical evidence) sehingga dapat diolah kepengujian selanjutnya.

Tabel. 14 Uji Validitas Variabel Independen Sabar (Patience)

\begin{tabular}{|c|c|c|c|}
\hline Pernyataan & r Hitung & r Tabel & Keterangan \\
\hline S1 & 0,468 & 0,209 & Valid \\
\hline S2 & 0,639 & 0,209 & Valid \\
\hline S3 & 0,465 & 0,209 & Valid \\
\hline S4 & 0,640 & 0,209 & Valid \\
\hline
\end{tabular}

Berdasarkan Tabel.14 menunjukkan bahwa nilai $\mathrm{r}$ tabel Product Moment pada signifikansi 0,05 dan 2 sisi dengan nilai $\mathrm{N}=96, \mathrm{df}=96-2=94$ nilai yang didapat adalah 0,209 . Sedangkan nilai $r$ hitung diketahui bahwa $r$ hitung $\geq \mathrm{r}$ tabel, maka dapat disimpulkan bahwa semua butir pernyataan untuk variabel sabar (patience) adalah valid, dan tidak terdapat pernyataan 
yang tidak valid dalam semua butir pernyataan variabel sabar (patience) sehingga dapat diolah kepengujian selanjutnya.

Tabel. 15 Uji Validitas Variabel Independen Janji (Promise)

\begin{tabular}{|c|c|c|c|}
\hline Pernyataan & r Hitung & r Tabel & Keterangan \\
\hline J1 & 0,577 & 0,209 & Valid \\
\hline J2 & 0,671 & 0,209 & Valid \\
\hline J3 & 0,507 & 0,209 & Valid \\
\hline J4 & 0,533 & 0,209 & Valid \\
\hline
\end{tabular}

Berdasarkan Tabel.15 menunjukkan bahwa nilai $\mathrm{r}$ tabel Product Moment pada signifikansi 0,05 dan 2 sisi dengan nilai $\mathrm{N}=96, \mathrm{df}=96-2=94$ nilai yang didapat adalah 0,209 . Sedangkan nilai $r$ hitung diketahui bahwa $r$ hitung $\geq \mathrm{r}$ tabel, maka dapat disimpulkan bahwa semua butir pernyataan untuk variabel janji (promise) adalah valid, dan tidak terdapat pernyataan yang tidak valid dalam semua butir pernyataan variabel janji (promise) sehingga dapat diolah kepengujian selanjutnya.

Tabel. 16 Uji Validitas Variabel Dependen Keputusan Pembelian

\begin{tabular}{|c|c|c|c|}
\hline Pernyataan & r Hitung & r Tabel & Keterangan \\
\hline KP1 & 0,368 & 0,209 & Valid \\
\hline KP2 & 0,448 & 0,209 & Valid \\
\hline KP3 & 0,674 & 0,209 & Valid \\
\hline KP4 & 0,341 & 0,209 & Valid \\
\hline KP5 & 0,426 & 0,209 & Valid \\
\hline KP6 & 0,660 & 0,209 & Valid \\
\hline
\end{tabular}

Berdasarkan Tabel.16 menunjukkan bahwa nilai $\mathrm{r}$ tabel Product Moment pada signifikansi 0,05 dan 2 sisi dengan nilai $\mathrm{N}=96, \mathrm{df}=96-2=94$ nilai yang didapat adalah 0,209. Sedangkan nilai $r$ hitung diketahui bahwa $r$ hitung $\geq r$ tabel, maka dapat disimpulkan bahwa semua butir pernyataan untuk variabel keputusan pembelian adalah valid, dan tidak terdapat pernyataan yang tidak valid dalam semua butir pernyataan variabel keputusan pembelian sehingga dapat diolah kepengujian selanjutnya.

Tabel. 17 Hasil Hasil Uji Relibiltas Instrumen

\begin{tabular}{|l|c|c|c|}
\hline \multicolumn{1}{|c|}{ Variabel } & Cronbach's Alpha & Nilai Kritis & Keterangan \\
\hline Produk(Product) & 0,715 & 0,60 & Reliabel \\
\hline Persepsi Harga (Price) & 0,667 & 0,60 & Reliabel \\
\hline Tempat (Place) & 0,677 & 0,60 & Reliabel \\
\hline Promosi(Promotion) & 0,666 & 0,60 & Reliabel \\
\hline SDM (People) & 0,638 & 0,60 & Reliabel \\
\hline Proses (Process) & 0,630 & 0,60 & Reliabel \\
\hline Bukti Fisik(Physical Evidence) & 0,605 & 0,60 & Reliabel \\
\hline Sabar (Patience) & 0,680 & 0,60 & Reliabel \\
\hline
\end{tabular}




\begin{tabular}{|l|l|l|l|}
\hline Janji (Promise) & 0,701 & 0,60 & Reliabel \\
\hline Keputusan Pembelian & 0,668 & 0,60 & Reliabel \\
\hline
\end{tabular}

Berdasarkan tabel.17 dapat diketahui bahwa hasil pengujian reliabilitas pada enam variabel diperoleh nilai Cronboach Alpha berada di atas angka 0,6. Dengan demikian dapat dikatakan bahwa semua konsep pengukur untuk masing-masing variabel dari kuesioner yang telah disebarkan adalah reliable. Selanjutnya item-item pada masing-masing variabel tersebut layak digunakan sebagai alat ukur.

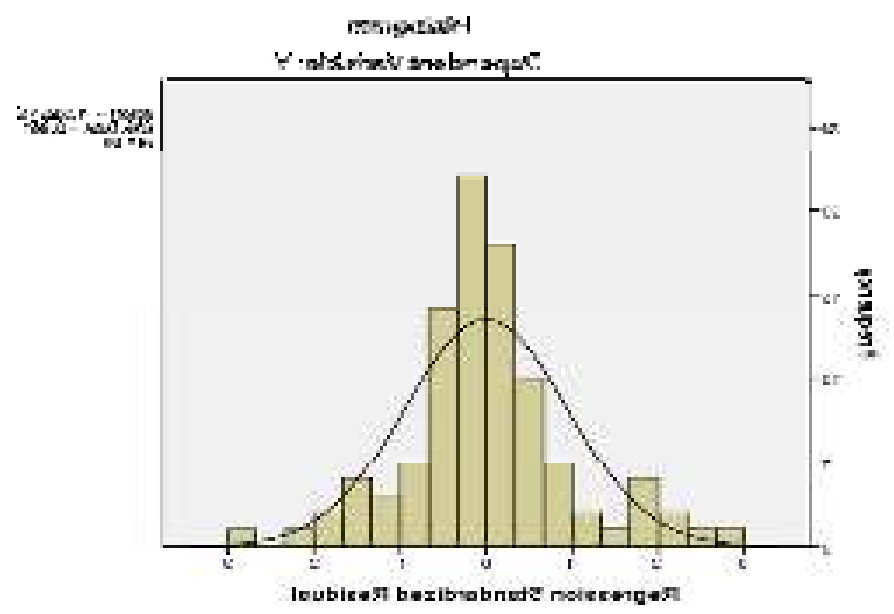

Gambar.1 Kurva Histogram

Berdasarkan gambar IV.1 dapat dilihat bahwa distribusi data yang membentuk lonceng dengan kedua sisi yang tidak hingga, berdasarkan uji normalitas variabel dependent dan variabel independent memiliki distribusi normal. Hal ini dapat disimpulkan bahwa variabel dalam penelitian ini tidak memiliki variabel pengganggu yang mengakibatkan data tidak berdistribusi normal.

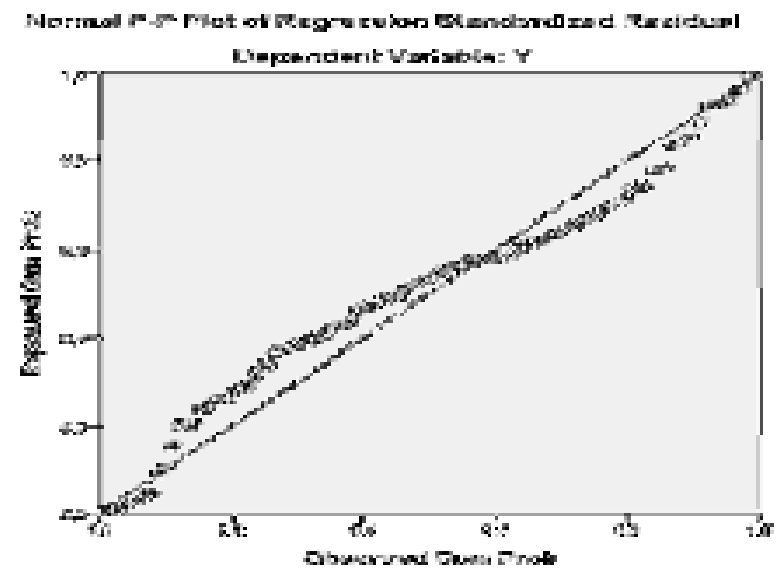

Gambar .2 Kurva Normal p-plot

Berdasarkan gambar IV.2 dapat dilihat bahwa uji normalitas menggunakan p-plot di atas, data variabel dependent dan variabel 
independent mempunyai distribusi normal, karena data-data yang telah diolah banyak menyebar disekitar garis diagonal dan mengikuti garis diagonal tersebut, ini berarti data yang telah dilakukan pengujian memiliki distribusi normal dan dapat digunakan.

\section{Tabel.18 Uji Multikolinieritas}

\begin{tabular}{|c|c|c|c|c|c|c|c|c|}
\hline \multicolumn{9}{|c|}{ Coefficients $^{a}$} \\
\hline & & \multicolumn{2}{|c|}{$\begin{array}{c}\text { Unstandardized } \\
\text { Coefficients }\end{array}$} & \multirow{2}{*}{$\begin{array}{c}\begin{array}{c}\text { Standardized } \\
\text { Coefficients }\end{array} \\
\text { Beta } \\
\end{array}$} & \multirow[b]{2}{*}{$\mathrm{t}$} & \multirow[b]{2}{*}{ Sig. } & \multicolumn{2}{|c|}{$\begin{array}{c}\text { Collinearity } \\
\text { Statistics }\end{array}$} \\
\hline \multicolumn{2}{|c|}{ Model } & $\mathrm{B}$ & Std. Error & & & & Tolerance & VIF \\
\hline 1 & (Constant) & $-18,622$ & 2,327 & & $\begin{array}{c}- \\
8,004 \\
\end{array}$ & 000 & & \\
\hline & Produk & , 072 & ,036 & , 109 & 2,012 & ,047 & ,625 & 1,599 \\
\hline & $\begin{array}{l}\text { Persepsi } \\
\text { Harga }\end{array}$ & ,203 & 042 & ,221 & 4,812 & , 000 & ,863 & 1,159 \\
\hline & Tempat & ,155 & ,046 & , 179 & 3,397 & ,001 & ,651 & 1,535 \\
\hline & Promosi & ,095 & ,039 & ,140 & 2,425 & ,017 & ,542 & 1,844 \\
\hline & SDM/Orang & ,528 &, 066 & ,477 & 8,053 & , 000 & ,519 & 1,928 \\
\hline & Proses & ,209 & ,083 & , 140 & 2,518 & ,014 & ,586 & 1,706 \\
\hline & Bukti Fisik & ,223 & ,084 & ,136 & 2,657 & ,009 & ,690 & 1,449 \\
\hline & Sabar & ,199 & ,078 & ,141 & 2,568 & ,012 & ,599 & 1,669 \\
\hline & Janji & ,178 &, 067 & ,133 & 2,648 & ,010 & ,724 & 1,381 \\
\hline
\end{tabular}

Berdasarkan tabel.18 maka dapat dilihat bahwa nilai VIF dari produk (product) sebanyak 1,599 yang mana di bawah angka 10 (VIF=10), variabel harga (price) dengan nilai 1,159<10, variabel tempat (place) dengan nilai $1,535<10$, variabel promosi (promotion) dengan nilai 1,844<10, variabel SDM (people) dengan nilai $1,928<10$, variabel proses (process) dengan nilai $1,706<10$, variabel bukti fisik (physical evidence) dengan nilai $1,449<10$, variabel sabar (patience) dengan nilai 1,669<10, dan variabel janji (promise) dengan nilai $1,381<10$. Dari semua variabel yang diteliti sama-sama berada di bawah 10 (VIF=10), hal ini berarti tidak terjadi multikolinieritas antar variabel dalam penelitian ini.

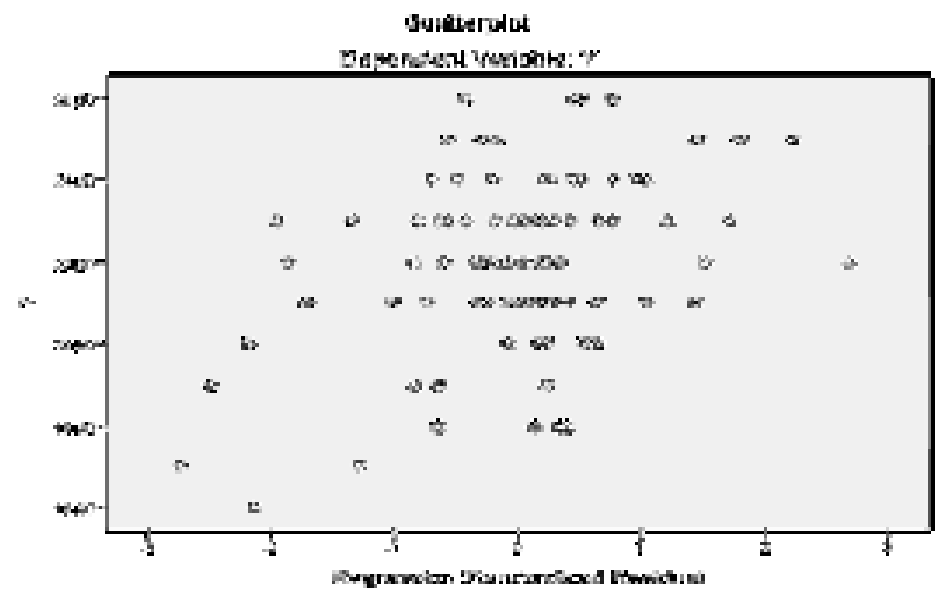

Gambar.3 Uji Heterokedastisitas 
Berdasarkan gambar IV.3, terlihat tampilan pada scatterplot terlihat bahwa plot menyebar secara acak diatas maupun dibawah angka nol pada sumbu regression studentized residual. Oleh karena itu maka berdasarkan uji heteroskedastisitas menggunakan metode analisis grafik, pada model regresi yang terbentuk dinyatakan tidak terjadi gejala heteroskedastisitas.

Tabel.19 Uji Analisis Linear Berganda

\begin{tabular}{|c|c|c|c|c|c|}
\hline \multicolumn{6}{|c|}{ Coefficients $^{\mathbf{a}}$} \\
\hline \multirow[b]{2}{*}{ Model } & \multicolumn{2}{|c|}{ Unstandardized Coefficients } & \multirow{2}{*}{$\begin{array}{c}\text { Standardized } \\
\text { Coefficients }\end{array}$} & \multirow[b]{2}{*}{$\mathrm{t}$} & \multirow[b]{2}{*}{ Sig. } \\
\hline & $\mathrm{B}$ & Std. Error & & & \\
\hline 1 (Constant) & $-18,622$ & 2,327 & & $-8,004$ &, 000 \\
\hline Produk & ,072 & ,036 & ,109 & 2,012 & 047 \\
\hline $\begin{array}{l}\text { Persepsi } \\
\text { Harga }\end{array}$ & 203 & ,042 & 221 & 4,812 & 000 \\
\hline Tempat & ,155 &, 046 & ,179 & 3,397 &, 001 \\
\hline Promosi &, 095 & 039 & ,140 & 2,425 & ,017 \\
\hline SDM/Orang & ,528 &, 066 & ,477 & 8,053 &, 000 \\
\hline Proses & ,209 & ,083 & ,140 & 2,518 &, 014 \\
\hline Bukti Fisik & ,223 & ,084 & ,136 & 2,657 & ,009 \\
\hline Sabar & ,199 & ,078 & ,141 & 2,568 & ,012 \\
\hline Janji &, 178 &, 067 & ,133 & 2,648 & ,010 \\
\hline
\end{tabular}

Berdasarkan Tabel.19, dapat diketahui persamaan regresi linear berganda sebagai berikut:

$$
\begin{gathered}
Y=a+b_{1} X_{1}+b_{2} X_{2}+b_{3} X_{3}+b_{4} X_{4}+b_{5} X_{5}+b_{6} X_{6}+b_{7} X_{7}+b_{8} X_{8}+b_{9} X_{9}+e \\
Y=-18,622+0,072 X_{1}+0,203 X_{2}+0,155 X_{3}+0,095 X_{4}+0528 X_{5}+ \\
0,209 X_{6}+0,223 X_{7}+0,199 X_{8}+0,178 X_{9}+e
\end{gathered}
$$

Arti angka-angka dalam persamaan regresi diatas adalah :

1) Nilai konstanta (a) sebesar -18,622. Artinya adalah apabila produk, persepsi harga, tempat, promosi, sumber daya manusia, proses, bukti fisik, sabar, dan janji diasumsikan bernilai (0), maka keputusan konsumen membeli produk pada sentra oleh-oleh makanan di Pasar Wisata Pekanbaru akan mengalami penurunan sebesar 18,622.

2) Nilai koefisien regresi 0,072 menyatakan bahwa jika produk mengalami peningkatan 1 satuan, maka keputusan pembelian akan mengalami peningkatan sebesar 0,072 .

3) Nilai koefisien regresi 0,203 menyatakan bahwa jika persepsi harga mengalami peningkatan 1 satuan, maka keputusan pembelian akan mengalami peningkatan sebesar 0,203 .

4) Nilai koefisien regresi 0,155 menyatakan bahwa jika tempat mengalami peningkatan 1 satuan, maka keputusan pembelian akan mengalami 
peningkatan sebesar 0,155 .

5) Nilai koefisien regresi 0,095 menyatakan bahwa jika promosi mengalami peningkatan 1 satuan, maka keputusan pembelian akan mengalami peningkatan sebesar 0,095 .

6) Nilai koefisien regresi 0,528 menyatakan bahwa jika sumber daya manusia mengalami peningkatan 1 satuan, maka keputusan pembelian akan mengalami peningkatan sebesar 0,528.

7) Nilai koefisien regresi 0,209 menyatakan bahwa jika proses mengalami peningkatan 1 satuan, maka keputusan pembelian akan mengalami peningkatan sebesar 0,209.

8) Nilai koefisien regresi 0,223 menyatakan bahwa jika bukti fisik mengalami peningkatan 1 satuan, maka keputusan pembelian akan mengalami peningkatan sebesar 0,223 .

9) Nilai koefisien regresi 0,199 menyatakan bahwa jika sabar mengalami peningkatan 1 satuan, maka keputusan pembelian akan mengalami peningkatan sebesar 0,199.

10)Nilai koefisien regresi 0,178 menyatakan bahwa jika janji mengalami peningkatan 1 satuan, maka keputusan pembelian akan mengalami peningkatan sebesar 0,178 .

11)Standar error (e) merupakan variabel acak dan mempunyai distribusi probabilitas yang mewakili semua faktor yang mempunyai pengaruh terhadap Y tetapi tidak dimasukkan dalam persamaan.

Berdasarkan tabel.19, maka hasil pengujian hipotesisnya untuk uji t adalah sebagai berikut:

\section{1) Variabel Produk (Product)}

Nilai $t_{\text {hitung }}$ produk (product) yaitu 2,012 dan $t_{\text {tabel }}$ yang diperoleh sebanyak 0,200. Jadi $t_{\text {hitung }}>t_{\text {tabel }}(2,012>0,200)$, dengan nilai signifikasi sebanyak $(0,047<0,05)$, maka Ha diterima dan Ho ditolak, sehingga dapat dinyatakan bahwa variabel produk memiliki pengaruh positif dan signifikan terhadap keputusan konsumen membeli produk pada sentra oleh-oleh makanan di Pasar Wisata Pekanbaru. Adapun besarnya pengaruh produk (product) terhadap keputusan konsumen membeli produk pada sentra oleh-oleh makanan di Pasar Wisata Pekanbaru sebesar 0,109.

\section{2) Variabel Persepsi Harga (Price)}

Nilai $t_{\text {hitung }}$ harga (price) yaitu 4,812 dan $t_{\text {htabel }}$ yang diperoleh sebanyak 0,200 . Jadi $t_{\text {hitung }}>t_{\text {tabel }}(4,812>0,200)$, dengan nilai signifikasi sebanyak $(0,000<0,05)$, maka Ha diterima dan Ho ditolak, sehingga dapat dinyatakan variabel persepsi harga (price perception) berpengaruh signifikan dan memiliki arahan positif terhadap keputusan konsumen membeli produk pada sentra oleh-oleh makanan di Pasar Wisata 
Pekanbaru. Adapun pengaruh persepsi harga (price perception) terhadap keputusan konsumen membeli produk pada sentra oleh-oleh makanan di Pasar Wisata Pekanbaru sebesar 0,221.

\section{3) Variabel Tempat (Place)}

Nilai thitung tempat (place) yaitu 3,397 dan tabel yang diperoleh sebanyak 0,200 . Jadi $t_{\text {hitung }}>t_{\text {tabel }}(3,397>0,200)$, dengan nilai signifikasi sebanyak $(0,000<0,05)$, maka Ha diterima dan Ho ditolak, sehingga dapat dinyatakan variabel tempat (place) berpengaruh positif dan signifikan terhadap keputusan konsumen membeli produk pada sentra oleh-oleh makanan di Pasar Wisata Pekanbaru. Adapun besarnya pengaruh tempat (place) terhadap keputusan konsumen membeli produk pada sentra oleh-oleh makanan di Pasar Wisata Pekanbaru sebesar 0,179.

4) Variabel Promosi (Promotion)

Nilai thitung promosi (promotion) yaitu 2,425 dan tabel yang diperoleh sebanyak 0,200 . Jadi $t_{\text {hitung }}>t_{\text {tabel }}(2,425>0,200)$, dengan nilai signifikasi sebanyak $(0,017<0,05)$, maka Ha diterima dan Ho ditolak, sehingga dapat dinyatakan variabel promosi (promotion) berpengaruh positif dan signifikan terhadap keputusan konsumen membeli produk pada sentra oleh-oleh makanan di Pasar Wisata Pekanbaru. Adapun besarnya pengaruh promosi (promotion) terhadap keputusan konsumen membeli produk pada sentra oleh-oleh makanan di Pasar Wisata Pekanbaru sebesar 0,140.

\section{5) Variabel Sumber Daya Manusia/SDM (People)}

Nilai $t_{\text {hitung }}$ sumber daya manusia /SDM (people) yaitu 8,053 dan $t_{\text {tabel }}$ yang diperoleh sebanyak 0,200 Jadi $t_{\text {hitung }}>t_{\text {tabel }}(8,053>0,200)$, dengan nilai signifikasi sebanyak $(0,000<0,05)$, maka Ha diterima dan Ho ditolak, sehingga dapat dinyatakan variabel sumber daya manusia/SDM (people) berpengaruh positif dan signifikan dan terhadap keputusan konsumen membeli produk pada sentra oleh-oleh makanan di Pasar Wisata Pekanbaru. Adapun besarnya pengaruh sumber daya manusia /SDM (people) terhadap keputusan konsumen membeli produk pada sentra oleh-oleh makanan di Pasar Wisata Pekanbaru sebesar 0,477.

\section{6) Variabel Proses (Process)}

Nilai thitung proses (process) yaitu 2,518 dan tabel yang diperoleh sebanyak 0,200 Jadi $t_{\text {hitung }}>t_{\text {tabel }}(2,518>0,200)$, dengan nilai signifikasi sebanyak $(0,014<0,05)$, maka Ha diterima dan Ho ditolak, sehingga dapat dinyatakan variabel proses (process) berpengaruh positif dan signifikan dan terhadap keputusan konsumen membeli produk pada sentra oleh-oleh makanan di Pasar Wisata Pekanbaru. Adapun besarnya pengaruh proses (process) terhadap keputusan konsumen membeli 
produk pada sentra oleh-oleh makanan di Pasar Wisata Pekanbaru sebesar 0,140.

\section{7) Variabel Bukti Fisik (Physical Evidence)}

Nilai $t_{\text {hitung }}$ bukti fisik (physical evidence) yaitu 2,657 dan $t_{\text {tabel }}$ yang diperoleh sebanyak 0,200 Jadi $t_{\text {hitung }}>t_{\text {tabel }}(2,657>0,200)$, dengan nilai signifikasi sebanyak $(0,009<0,05)$, maka Ha diterima dan Ho ditolak, sehingga dapat dinyatakan variabel bukti fisik (physical evidence) berpengaruh positif dan signifikan dan terhadap keputusan konsumen membeli produk pada sentra oleh-oleh makanan di Pasar Wisata Pekanbaru. Adapun besarnya pengaruh bukti fisik (physical evidence) terhadap keputusan konsumen membeli produk pada sentra oleh-oleh makanan di Pasar Wisata Pekanbaru sebesar 0,136.

8) Variabel Sabar (Patience)

Nilai thitung sabar (patience) yaitu 2,568 dan tabel yang diperoleh sebanyak 0,200 Jadi $t_{\text {hitung }}>t_{\text {tabel }}(2,568>0,200)$, dengan nilai signifikasi sebanyak $(0,012<0,05)$, maka Ha diterima dan Ho ditolak, sehingga dapat dinyatakan variabel sabar (patience) berpengaruh positif dan signifikan dan terhadap keputusan konsumen membeli produk pada sentra oleh-oleh makanan di Pasar Wisata Pekanbaru. Adapun besarnya pengaruh sabar (patience) terhadap keputusan konsumen membeli produk pada sentra oleh-oleh makanan di Pasar Wisata Pekanbaru sebesar 0,141.

\section{9) Variabel Janji (Promise)}

Nilai $t_{\text {hitung }}$ janji (promise) yaitu 2,648 dan $t_{\text {tabel }}$ yang diperoleh sebanyak 0,200 Jadi $t_{\text {hitung }}>t_{\text {tabel }}(2,648>0,200)$, dengan nilai signifikasi sebanyak $(0,010<0,05)$, maka Ha diterima dan Ho ditolak, sehingga dapat dinyatakan variabel janji (promise) berpengaruh positif dan signifikan dan terhadap keputusan konsumen membeli produk pada sentra oleh-oleh makanan di Pasar Wisata Pekanbaru. Adapun besarnya pengaruh janji (promise) terhadap keputusan konsumen membeli produk pada sentra oleh-oleh makanan di Pasar Wisata Pekanbaru sebesar 0,133.

Tabel.20 Hasil Uji Simultan (F)

\begin{tabular}{|c|c|c|c|c|c|c|}
\hline \multicolumn{7}{|c|}{ ANOVA $^{\mathbf{a}}$} \\
\hline \multicolumn{2}{|c|}{ Model } & Sum of Squares & $\mathrm{df}$ & Mean Square & $\mathrm{F}$ & Sig. \\
\hline \multirow[t]{3}{*}{1} & Regression & 355,160 & 9 & 39,462 & 51,553 &, $000^{\mathrm{b}}$ \\
\hline & Residual & 65,830 & 86 & ,765 & & \\
\hline & Total & 420,990 & 95 & & & \\
\hline \multicolumn{7}{|c|}{ a. Dependent Variable: Keputusan Pembelian } \\
\hline \multicolumn{7}{|c|}{$\begin{array}{l}\text { b. Predictors: (Constant), Janji, Sumber Daya Manusia/SDM, Persepsi Harga, } \\
\text { Tempat, Produk, Bukti Fisik, Proses, Sabar, Promosi }\end{array}$} \\
\hline
\end{tabular}


Berdasarkan uji F pada Tabel.20 diperoleh nilai F sebanyak 51,553dan nilai $\mathrm{F}$ tabel yang diperoleh sebanyak 1,99 dengan tingkat signifikansi 0,000< 0,05 . Jadi $\mathrm{F}$ hitung $>\mathrm{F}$ tabel $(51,553>1,99)$, maka Ho ditolak dan Ha diterima. Nilai signifikansi $\mathrm{F}$ sebanyak 0,000, karena niai sig $\mathrm{F}<0,05$, maka Ho ditolak dan Ha diterima.

Tabel.21 Hasil Uji Koefisien Determinasi (R2)

\begin{tabular}{|c|c|c|c|c|c|}
\hline \multicolumn{6}{|c|}{ Model Summaryb } \\
\hline Model & $\mathrm{R}$ & R Square & $\begin{array}{l}\text { Adjusted R } \\
\text { Square }\end{array}$ & $\begin{array}{l}\text { Std. Error of } \\
\text { the Estimate }\end{array}$ & Durbin-Watson \\
\hline 1 &, $918^{\mathrm{a}}$ & ,844 & ,827 & ,87491 & 1,443 \\
\hline
\end{tabular}

Berdasarkan Tabel.21 dapat diketahui bahwa nilai Adjusted $R$ Square pada penelitian ini adalah 0,844 . Hal ini berarti $84,4 \%$ variabel keputusan konsumen membeli produk pada sentra oleh-oleh makanan di Pasar Wisata Pekanbaru dapat dijelaskan oleh variabel produk (product), persepsi harga (price perception), tempat (place), promosi (promotion), SDM (people), proses (process), bukti fisik (physical evidence), sabar (patience), dan janji (promise). Sedangkan sisanya dijelaskan oleh variabel lain yang tidak dimasukkan dalam penelitian ini.

\section{Pembahasan Analisis Data}

\section{Pengaruh Bauran Pemasaran Syariah terhadap Keputusan Pembelian}

Berdasarkan hasil penelitian tentang (Pengaruh Bauran Pemasaran Syariah terhadap Keputusan Konsumen Membeli Produk pada Sentra Oleh-oleh Makanan di Pasar Wisata Pekanbaru), secara parsial diperoleh hasil sebagai berikut:

\section{a. Pengaruh Produk (Product) terhadap Keputusan Pembelian}

Berdasarkan hasil penelitian yang dilakukan maka dapat diperoleh bahwa nilai $t_{\text {hitung }}$ produk (product) yaitu 2,012 dan $t_{\text {tabel yang diperoleh }}$ sebanyak 0,200 . Jadi $t_{\text {hitung }}>t_{\text {tabel }}(2,012>0,200)$, dengan nilai signifikasi sebanyak $(0,047<0,05)$, maka Ha diterima dan Ho ditolak, sehingga dapat dinyatakan bahwa variabel produk (product) memiliki pengaruh positif dan signifikan terhadap keputusan konsumen membeli produk pada sentra oleh-oleh makanan di Pasar Wisata Pekanbaru.

Hasil ini didukung dengan penelitian yang dilakukan oleh Rika Paujiah, Ahmad Mulyadi Kosim, Syarifah Gustiawati, menunjukkan bahwa adanya pengaruh yang signifikan antara variabel produk terhadap keputusan pembelian. Terlihat thitung $(3,739)>t_{\text {tabel }} 1.988$, dengan tingkat signifikan $0,000<0,005(5 \%)$ yang berarti label halal berpengaruh positif 
dan signifikan terhadap keputusan pembelian produk makanan d'Best0 pada konsumen did'BestO Bondes Bogor. Hal ini berarti semakin tinggi tingkat keyakinan label halal, maka semakin tinggi keputusan pembelian. ${ }^{9}$ Penelitian lain oleh Imam Heryanto, menunjukkan bahwa adanya pengaruh yang signifikan antara variabel harga terhadap keputusan pembelian. ${ }^{10}$

Nilai unstandardized beta variabel produk (product) bernilai positif terhadap keputusan pembelian sebanyak 0,072 dengan signifikansi 0,047 yang berarti < 0,05. Hal ini dapat diartikan bahwa setiap peningkatan produk (product) sebanyak 1 satuan, maka keputusan pembelian akan mengalami peningkatan sebanyak 0,072 atau 7,2\% (dengan asumsi variabel yang lain nilainya tetap). Hal ini juga menunjukkan bahwa semakin baik produk (product), maka semakin meningkat keputusan konsumen membeli produk pada sentra oleh-oleh makanan di Pasar Wisata Pekanbaru.

\section{b. Pengaruh Persepsi Harga (Price) terhadap Keputusan Pembelian}

Berdasarkan hasil penelitian yang dilakukan maka dapat diperoleh bahwa nilai thitung persepsi harga (price) yaitu 4,812 dan thtabel yang diperoleh sebanyak 0,200 . Jadi $t_{\text {hitung }}>t_{\text {tabel }}(4,812>0,200)$, dengan nilai signifikasi sebanyak $(0,000<0,05)$, maka Ha diterima dan Ho ditolak, sehingga dapat dinyatakan variabel harga (price) berpengaruh signifikan dan memiliki arahan positif terhadap keputusan konsumen membeli produk pada sentra oleh-oleh makanan di Pasar Wisata Pekanbaru.

Penelitian juga didukung oleh Sudirman, Syamsul Bachri dan Elimawaty Rombe ${ }^{11}$, yang menunjukkan bahwa variabel harga memberikan pengaruh positif terhadap keputusan pembelian. Hasil ini menunjukkan bahwa persepsi harga dapat membantu konsumen dalam memutuskan pembelian sebuah produk. Dan sejalan dengan penelitian lain oleh Wini Bin Garib, S. L. H. V. Joyce Lapian, dan Lisbeth Mananeke (2019) ${ }^{12}$, bahwa variabel persepsi harga secara parsial berpengaruh

${ }^{9}$ Rika Paujiah, Ahmad Mulyadi Kosim, Syarifah Gustiawati, Pengaruh Bauran Pemasaran Syariah dan Label Halal terhadap Keputusan Pembelian, Al Maal : Journal of Islamic Economics and Banking, E-ISSN : 580 - 3816, Volume : No 1 Vol 2 Bulan Januari Tahun 2020, Jurnal Online diakses pada tanggal 7 Juni 2021

${ }^{10}$ Imam Heryanto, Analisis Pengaruh Produk, Harga, Distribusi, dan Promosi terhadap Keputusan Pembelian serta Implikasinya pada Kepuasan Pelanggan, 2015, JEBE, Volume. 9, Nomor. 2. Jurnal Online diakses pada tanggal 9 Juni 2021

11 Sudirman, Syamsul Bachri dan Elimawaty Rombe, Pengaruh Bauran Pemasaran Terhadap Keputusan Pembelian City Car Kiapicanto Pada Pt. Kars Inti Amanah, (Kalla Kia) Palu, e-Jurnal Katalogis, Volume 3 Nomor 12, Desember 2015. Jurnal online diakses pada Tanggal 7 Juni 2021.

12 Wini Bin Garib, S. L. H. V. Joyce Lapian, dan Lisbeth Mananeke, Pengaruh Bauran Promosi, Persepsi Harga dan Kualitas Produk terhadap Keputusan Pembelian Sepeda Motor 
signifikan terhadap keputusan pembelian dengan tingkat signifikasi pvalue $=0,000<0,05$.

Nilai unstandardized beta persepsi harga (price) bernilai positif terhadap keputusan pembelian sebanyak 0,203 dengan signifikansi 0,000 yang berarti $<0,05$. Hal ini dapat diartikan bahwa setiap peningkatan harga (price) sebanyak 1 satuan, maka keputusan pembelian akan mengalami peningkatan sebanyak 0,203 atau 20,3\% (dengan asumsi variabel yang lain nilainya tetap). Hal ini juga menunjukkan bahwa semakin baik harga (price), maka semakin meningkat keputusan konsumen membeli produk pada sentra oleh-oleh makanan di Pasar Wisata Pekanbaru.

\section{c. Pengaruh Tempat (Place) terhadap Keputusan Pembelian}

Berdasarkan hasil penelitian yang dilakukan maka dapat diperoleh bahwa nilai thitung tempat (place) yaitu 3,397 dan tabel yang diperoleh sebanyak 0,200 . Jadi $t_{\text {hitung }}>t_{\text {tabel }}(3,397>0,200)$, dengan nilai signifikasi sebanyak $(0,001<0,05)$, maka Ha diterima dan Ho ditolak, sehingga dapat dinyatakan variabel tempat (place) berpengaruh positif dan signifikan terhadap keputusan konsumen membeli produk pada sentra oleh-oleh makanan di Pasar Wisata Pekanbaru.

Hasil ini didukung dengan penelitian yang dilakukan oleh Novelia Al-Raafi Rizki Adinda Sutrisno, Joko Widodo, Mukhamad Zulianto, menunjukkan bahwa adanya pengaruh yang signifikan antara variabel tempat (place) terhadap keputusan pembelian produk RM ayam bakar wong Solo Jember. Bahwa setiap variabel pada penelitian ini berpengaruh secara positif terhadap pembelian produk RM ayam bakar wong Solo Jember. ${ }^{13}$

Nilai unstandardized beta tempat (place) bernilai positif terhadap keputusan pembelian sebanyak 0,155 dengan signifikansi 0,001 yang berarti $<0,05$. Hal ini dapat diartikan bahwa setiap peningkatan tempat (place) sebanyak 1 satuan, maka keputusan pembelian akan mengalami peningkatan sebanyak 0,155 atau 15,5\% (dengan asumsi variabel yang lain nilainya tetap). Hal ini juga menunjukkan bahwa semakin baik tempat (place), maka semakin meningkat keputusan konsumen membeli produk pada sentra oleh-oleh makanan di Pasar Wisata Pekanbaru.

\section{d. Pengaruh Promosi (Promotion) terhadap Keputusan Pembelian}

\footnotetext{
Yamaha pada PT. Hasjrat Abadi Sentral Yamaha Malalayang, Jurnal WMBA, Vol. 7 No. 1 Januari 2019. Jurnal online diakses pada tanggal 6 Juni 2021

${ }^{13}$ Novelia Al-Raafi Rizki Adinda Sutrisno, Joko Widodo, Mukhamad Zulianto, Pengaruh Bauran Pemasaran Terhadap Keputusan Pembelian Produk RM Ayam Bakar Wong Solo Jember, Jurnal Ilmiah Ilmu Pendidikan, Ilmu Ekonomi, dan Ilmu Sosial, Volume 12 Nomor 2 (2018), Jurnal Online diakses pada Tanggal 8 Juni 2021
} 
Berdasarkan hasil penelitian yang dilakukan maka dapat diperoleh

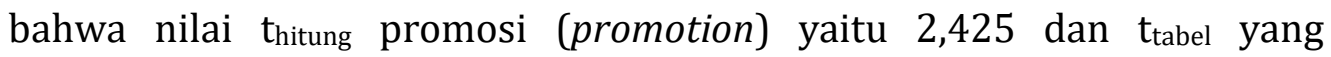
diperoleh sebanyak 0,200 . Jadi $t_{\text {hitung }}>t_{\text {tabel }}(2,425>0,200)$, dengan nilai signifikasi sebanyak $(0,017<0,05)$, maka Ha diterima dan Ho ditolak, sehingga dapat dinyatakan variabel promosi (promotion) berpengaruh positif dan signifikan terhadap keputusan konsumen membeli produk pada sentra oleh-oleh makanan di Pasar Wisata Pekanbaru.

Hasil ini didukung dengan penelitian yang dilakukan oleh Doharma Tetty Damanik, menunjukkan bahwa adanya pengaruh yang signifikan antara variabel promosi terhadap keputusan pembelian melalui perangkat komunikasi. Hasil pengujian hipotesis secara parsial bahwa nilai t-hitung variable promosi 5,342>1,987 t-tabel dan signifikansi hitung $0,000<0,05$ taraf signifikan, maka $\mathrm{H}_{0}$ ditolak $\mathrm{H}_{17}$ diterima. ${ }^{14}$

Nilai unstandardized beta promosi (promotion) bernilai positif terhadap keputusan pembelian sebanyak 0,095 dengan signifikansi 0,017 yang berarti $<0,05$. Hal ini dapat diartikan bahwa setiap peningkatan promosi (promotion) sebanyak 1 satuan, maka keputusan pembelian akan mengalami peningkatan sebanyak 0,095 atau 9,5\% (dengan asumsi variabel yang lain nilainya tetap). Hal ini juga menunjukkan bahwa semakin baik promosi (promotion), maka semakin meningkat keputusan konsumen membeli produk pada sentra oleh-oleh makanan di Pasar Wisata Pekanbaru.

\section{e. Pengaruh Sumber Daya Manusia/SDM (People) terhadap Keputusan Pembelian}

Berdasarkan hasil penelitian yang dilakukan maka dapat diperoleh bahwa nilai thitung sumber daya manusia /SDM (people) yaitu 8,053 dan $t_{\text {tabel }}$ yang diperoleh sebanyak 0,200 Jadi $t_{\text {hitung }}>t_{\text {tabel }}(8,053>0,200)$, dengan nilai signifikasi sebanyak $(0,000<0,05)$, maka Ha diterima dan Ho ditolak, sehingga dapat dinyatakan variabel sumber daya manusia/SDM (people) berpengaruh positif dan signifikan dan terhadap keputusan konsumen membeli produk pada sentra oleh-oleh makanan di Pasar Wisata Pekanbaru.

Hasil ini didukung dengan penelitian yang dilakukan oleh Solahuddin, menunjukkan bahwa adanya pengaruh yang signifikan antara variabel sumber daya manusia /SDM (people) terhadap keputusan Pembelian perumahan di Kota Pekanbaru. Bahwa setiap variabel pada

14 Doharma Tetty Damanik, Pengaruh Segmentasi Pasar, Bauran Pemasaran Terhadap Keputusan Pembelian Melalui Penggunaan Perangkat Komunikasi Sebagai Variable Intervening Pada Rumah Makan Tradisional Batak Umumnya Khususnya Pokkalan Nabolon Pematang Siantar, Magister Ilmu Manajemen Fakultas Ekonomi Dan Bisnis Universitas Sumatera Utara 2017, jurnal online diakses pada tanggal 7 Juni 2021 
penelitian ini berpengaruh secara positif terhadap pembelian perumahan di Kota Pekanbaru. ${ }^{15}$

Dalam Islamic marketing, SDM (people) diartikan dengan menjaga silaturrahim dan mengutamakan kepuasan konsumen. Pengaruh positif ini menunjukkan bahwa orang atau pedagang di Pasar Wisata sopan dalam melayani pelanggan, ramah dan santun, murah senyum, selalu bersikap jujur saat menerangkan produk pada pembeli. Sehingga dalam penelitian ini keberadaan orang (people) berpengaruh terhadap keputusan pembelian, sebagaimana tanggapan responden tentang Para pedagang di Pasar Wisata sangat ramah sebesar 3,85 \%. Sejalan dengan penelitian Amalia Ramadhanti, bahwasannya variabel orang dengan nilai sign $t_{\text {hitung }}$ sebesar $0,023<0,05$. Artinya variabel orang secara parsial berpengaruh signifikan terhadap keputusan pembelian. ${ }^{16}$

Nilai unstandardized beta sumber daya manusia /SDM (people) bernilai positif terhadap keputusan pembelian sebanyak 0,528 dengan signifikansi 0,000 yang berarti < 0,05. Hal ini dapat diartikan bahwa setiap peningkatan sumber daya manusia/SDM (people) sebanyak 1 satuan, maka keputusan pembelian akan mengalami peningkatan sebanyak 0,528 atau 52,8\% (dengan asumsi variabel yang lain nilainya tetap). Hal ini juga menunjukkan bahwa semakin baik sumber daya manusia /SDM (people), maka semakin meningkat keputusan konsumen membeli produk pada sentra oleh-oleh makanan di Pasar Wisata Pekanbaru.

\section{f. Pengaruh Proses (Process) terhadap Keputusan Pembelian}

Berdasarkan hasil penelitian yang dilakukan maka dapat diperoleh bahwa nilai $t_{\text {hitung }}$ proses (process) yaitu 2,518 dan $t_{\text {tabel }}$ yang diperoleh sebanyak 0,200 Jadi $t_{\text {hitung }}>t_{\text {tabel }}(2,518>0,200)$, dengan nilai signifikasi sebanyak $(0,014<0,05)$, maka Ha diterima dan Ho ditolak, sehingga dapat dinyatakan variabel proses (process) berpengaruh positif dan signifikan dan terhadap keputusan konsumen membeli produk pada sentra oleh-oleh makanan di Pasar Wisata Pekanbaru.

Hasil ini didukung dengan penelitian yang dilakukan oleh Solahuddin, menunjukkan bahwa adanya pengaruh yang signifikan antara variabel proses (process) terhadap keputusan Pembelian perumahan di Kota Pekanbaru. ${ }^{17}$ Nilai unstandardized beta proses (process) bernilai

${ }^{15}$ Solahuddin, Pengaruh Bauran Pemasaran Syari'ah Terhadap Keputusan Pembelian Perumahan Di Kota Pekanbaru, Mahasiswa Pascasarjana, UIN SUSKA RIAU 2020, . Jurnal Online diakses pada Tanggal 6 Juni 2021

${ }^{16}$ Amalia Ramadhanti, Pengaruh Bauran Pemasaran (7P) terhadap Keputusan Pembelian pada Giant Supermarket Mall Mesra Indah di Samarinda, ejournal Administrasi Bisnis, 2017, 5 (2): 269-282, jurnal Online diakses pada tanggal 8 Juni 2021

${ }^{17}$ Solahuddin, $\mathrm{Op}$. Cit 
positif terhadap keputusan pembelian sebanyak 0,209 dengan signifikansi 0,014 yang berarti <0,05. Hal ini dapat diartikan bahwa setiap peningkatan proses (process) sebanyak 1 satuan, maka keputusan pembelian akan mengalami peningkatan sebanyak 0,528 atau 52,8\% (dengan asumsi variabel yang lain nilainya tetap). Hal ini juga menunjukkan bahwa semakin baik proses (process), maka semakin meningkat keputusan konsumen membeli produk pada sentra oleh-oleh makanan di Pasar Wisata Pekanbaru.

\section{g. Pengaruh Bukti Fisik (Physical Evidence) terhadap Keputusan Pembelian}

Berdasarkan hasil penelitian yang dilakukan maka dapat diperoleh bahwa nilai thitung bukti fisik (physical evidence) yaitu 2,657 dan tabel yang diperoleh sebanyak 0,200 Jadi $t_{\text {hitung }}>t_{\text {tabel }}(2,657>0,200)$, dengan nilai signifikasi sebanyak $(0,009<0,05)$, maka Ha diterima dan Ho ditolak, sehingga dapat dinyatakan variabel bukti fisik (physical evidence) berpengaruh positif dan signifikan dan terhadap keputusan konsumen membeli produk pada sentra oleh-oleh makanan di Pasar Wisata Pekanbaru.

Hasil ini didukung dengan penelitian yang dilakukan oleh Dian Rahmayanti Rivai, menunjukkan bahwa adanya pengaruh yang signifikan antara variabel bukti fisik (physical evidence) terhadap keputusan pembelian kartu pada mahasiswa program pascasarjana Universitas Tadulako dengan nilai koefisien regresi 1.395 pada sig 0,049.18

Nilai unstandardized beta bukti fisik (physical evidence) bernilai positif terhadap keputusan pembelian sebanyak 0,223 dengan signifikansi 0,009 yang berarti < 0,05. Hal ini dapat diartikan bahwa setiap peningkatan bukti fisik (physical evidence) sebanyak 1 satuan, maka keputusan pembelian akan mengalami peningkatan sebanyak 0,223 atau 22,3\% (dengan asumsi variabel yang lain nilainya tetap). Hal ini juga menunjukkan bahwa semakin baik bukti fisik (physical evidence), maka semakin meningkat keputusan konsumen membeli produk pada sentra oleh-oleh makanan di Pasar Wisata Pekanbaru.

\section{h. Pengaruh Sabar (Patience) terhadap Keputusan Pembelian}

Berdasarkan hasil penelitian yang dilakukan maka dapat diperoleh bahwa nilai $t_{\text {hitung }}$ sabar (patience) yaitu 2,568 dan $t_{\text {tabel }}$ yang diperoleh sebanyak 0,200 Jadi $t_{\text {hitung }}>t_{\text {tabel }}(2,568>0,200)$, dengan nilai signifikasi sebanyak $(0,012<0,05)$, maka Ha diterima dan Ho ditolak, sehingga dapat dinyatakan variabel sabar (patience) berpengaruh positif dan

18 Rahmayanti Rivai, Pengaruh Bauran Pemasaran terhadap Keputusan Pembelian Kartu pada Mahasiswa Program Pascasarjana Universitas Tadulako, Mahasiswi Pascasarjana Universitas Tadulako 2019, jurnal Online diakses pada tanggal 8 Juni 2021 
signifikan dan terhadap keputusan konsumen membeli produk pada sentra oleh-oleh makanan di Pasar Wisata Pekanbaru.

Hasil ini didukung dengan penelitian yang dilakukan oleh Alfia Qorizah, menunjukkan bahwa adanya pengaruh yang signifikan antara variabel sabar (patience) terhadap terhadap keputusan pembelian konsumen terhadap niat menjadi mitra perspektif BMT Beringharjo. Berdasarkan pengujian bahwa untuk variabel sabar berpengaruh dan signifikan terhadap keputusan pembelian. Pengaruh positif ini menunjukkan bahwa pedagang yang berjualan di Pasar Wisata Pekanbtu senantiasa konsisten dalam menjaga kepercayaanya kepada semua pelanggan atau pembeli, selalu meningkatkan kepercayaanya terhadap pembeli atau konsumen, pedagang juga mempunyai manajemen waktu yang baik dan mempunyai hubungan baik antar sesama pelanggan. Sehingga menjadi faktor untuk para konsumen atau pembeli untuk melakukan pembelian produk oleh-oleh makanan di Pasar Wisata Pekanbaru. ${ }^{19}$

Nilai unstandardized beta sabar (patience) bernilai positif terhadap keputusan pembelian sebanyak 0,199 dengan signifikansi 0,012 yang berarti $<0,05$. Hal ini dapat diartikan bahwa setiap peningkatan sabar (patience) sebanyak Rp.1, maka keputusan pembelian akan mengalami peningkatan sebanyak 0,199 atau 19,9\% (dengan asumsi variabel yang lain nilainya tetap). Hal ini juga menunjukkan bahwa semakin baik sabar (patience), maka semakin meningkat keputusan konsumen membeli produk pada sentra oleh-oleh makanan di Pasar Wisata Pekanbaru.

\section{i. Pengaruh Janji (Promise) terhadap Keputusan Pembelian}

Berdasarkan hasil penelitian yang dilakukan maka dapat diperoleh bahwa nilai thitung janji (promise) yaitu 2,648 dan tabel yang diperoleh sebanyak 0,200 Jadi $t_{\text {hitung }}>t_{\text {tabel }}(2,648>0,200)$, dengan nilai signifikasi sebanyak $(0,010<0,05)$, maka Ha diterima dan Ho ditolak, sehingga dapat dinyatakan variabel janji (promise) berpengaruh positif dan signifikan dan terhadap keputusan konsumen membeli produk pada sentra oleh-oleh makanan di Pasar Wisata Pekanbaru.

Hasil ini didukung dengan penelitian yang dilakukan oleh Alfia Qorizah, menunjukkan bahwa adanya pengaruh yang signifikan antara variabel janji (promise) terhadap keptusan nasabah mengambil KPR

19 Tyas, Ari Prasetyo, Pengaruh Bauran Pemasaran Terhadap Niat Menjadi Mitra Perspektif Islam pada BMT Beringharjo Cabang Madiun 2014., JESTT, Volume. 1 No. 7, Jurnal Online diakses pada tanggal 9 Juni 2021 
Syariah, dengan Nilai signifikasi pada variabel janji (promise) sebesar $0,271>0,1$. Serta nilai thitung $2.473>1,683$ tabel. $^{20}$

Nilai unstandardized beta janji (promise) bernilai positif terhadap keputusan pembelian sebanyak 0,178 dengan signifikansi 0,010 yang berarti $<0,05$. Hal ini dapat diartikan bahwa setiap peningkatan janji (promise) sebanyak 1 satuan maka keputusan pembelian akan mengalami peningkatan sebanyak 0,178 atau $17,8 \%$ (dengan asumsi variabel yang lain nilainya tetap). Hal ini juga menunjukkan bahwa semakin baik janji (promise), maka semakin meningkat keputusan konsumen membeli produk pada sentra oleh-oleh makanan di Pasar Wisata Pekanbaru.

\section{j. Pengaruh Bauran Pemasaran Syariah terhadap Keputusan} Pembelian

Hasil penelitian yang dilakukan memberikan penjelasan bahwa bauran pemasaran syariah 9p (product, price, place, promotion, people, process, physical evidence, patience, promise) berpengaruh secara signifikan terhadap keputusan pembelian pada produk HNI HPAI di kota Pekanbaru. Hal ini ditunjukkan dengan hasil pengujian dengan uji F yang diperoleh nilai $\mathrm{F}$ hitung sebanyak 51,553 dan nilai $\mathrm{F}$ tabel yang diperoleh sebanyak 1,99 dengan tingkat signifikansi $0,000<0,05$. Jadi $F$ hitung $>F$ tabel $(51,553>1,99)$, maka Ho ditolak. Nilai signifikansi $F$ sebanyak 0,000, karena nilai sig $\mathrm{F}<0,05$, maka Ho ditolak dan Ha diterima. Maka hal ini bahwa bauran pemasaran syariah 9p (product, price, place, promotion, people, process, physical evidence, patience, promise) secara bersama-sama berpengaruh terhadap keputusan keputusan konsumen membeli produk pada sentra oleh-oleh makanan di Pasar Wisata Pekanbaru.

\section{Simpulan}

1. Secara parsial Variabel 9p, sabar (patience), dan janji (promise) berpengaruh positif dan signifikan antara bauran pemasaran syariah terhadap keputusan membeli produk pada sentra oleh-oleh makanan di Pasar Wisata Pekanbaru.

2. Secara simultan Variabel 9p, berpengaruh secara bersama-sama terhadap keputusan membeli produk pada sentra oleh-oleh makanan di Pasar Wisata Pekanbaru. Ketika seorang pemasar meningkatkan Bauran Pemasaran Syariah dalam melakukan kegiatan pemasaran maka keputusan membeli produk pada sentra oleh-oleh makanan di Pasar Wisata Pekanbaru akan mengalami peningkatan dan sebaliknya, apabila

${ }^{20}$ Alfia Qorizah, Pengaruh Bauran Pemasaran terhadap Keputusan Nasabah Mengambil KPR Syariah Bank Jatim Syariah Surabaya, Jurnal Ekonomi Islam, Volume 2 Nomor 2, tahun 2019, Jurnal Online diakses pada tanggal 8 Juni 2021 
seorang pemasar menurunkan strategi pemasaran maka akan mengalami penurunan terhadap keputusan membeli produk pada sentra oleh-oleh makanan di Pasar Wisata Pekanbaru.

3. Variabel bebas yang paling dominan mempengaruhi keputusan membeli produk pada sentra oleh-oleh makanan di Pasar Wisata Pekanbaru adalah variabel SDM/Orang sebesar 8,053. Selanjutnya diikuti varibel persepsi harga, variabel tempat, variabel bukti fisik, variabel janji, variabel sabar, variabel proses, variabel promosi, dan terakhir variabel produk. Hal pertama yang diperhatikan konsumen adalah SDM/Orang, diharapkan para pedagang untuk lebih meningkatkan dari segi keramahan, sopan santun, pelayanan dan kejujuran, karena apabila SDM/Orang tidak sesuai dengan apa yang diharapkan oleh konsumen makan maka akan mempengaruhi keputusan membeli produk pada sentra oleh-oleh makanan di Pasar Wisata Pekanbaru.

4. Berdasarkan nilai Adjusted $R$ Square pada penelitian ini adalah 0,844 . Hal ini berarti $84,4 \%$ variabel keputusan konsumen membeli produk pada sentra oleh-oleh makanan di Pasar Wisata Pekanbaru dapat dijelaskan oleh variabel produk (product), persepsi harga (price perception), tempat (place), promosi (promotion), SDM (people), proses (process), bukti fisik (physical evidence), sabar (patience), dan janji (promise). Sedangkan sisanya dijelaskan oleh variabel lain yang tidak dimasukkan dalam penelitian ini.

Namun, ada beberapa keterbatasan dalam penelitian ini, jumlah responden hanya 96 orang sehingga sampelnya terbatas. Untuk peneliti selanjutnya diharapkan melakukan penelitian yang berbeda dengan jumlah responden yang lebih besar sehingga mendekati keadaan sesungguhnya, kemudian peneliti selanjutnya agar menggunakan jenis lokasi yang berbeda dan penambahan indikator secara Islami dari berbagai sumber, dan diharapkan untuk peneliti selanjutnya memperluas cakupan wilayah penelitian atau lokasi penelitian seperti Pasar Wisata di tingkat antar provinsi maupun tingkat Nasional.

\section{Jurnal :}

Alfia Qorizah, Pengaruh Bauran Pemasaran terhadap Keputusan Nasabah Mengambil KPR Syariah Bank Jatim Syariah Surabaya, Jurnal Ekonomi Islam, Volume 2 Nomor 2, tahun 2019, Jurnal Online diakses pada tanggal 8 Juni 2021

Amalia Ramadhanti, Pengaruh Bauran Pemasaran (7P) terhadap Keputusan Pembelian pada Giant Supermarket Mall Mesra Indah di Samarinda, ejournal Administrasi Bisnis, 2017, 5 (2): 269-282, jurnal Online diakses pada tanggal 8 Juni 2021 
Angelina Rares, Rotinsulu Jopie Jorie, "The Effect Of The Price, Promotion, Location, Brand Image And Quality Products Towards The Purchase Decision Of Consumers At Bengkel Gaoel Store Manado Town Square ", Jurnal EMBA,Vol.3 No.2 Juni 2015 ISSN 2303-1174

Charlie Bernando Halomoan Samosir dan Arief Bowo Prayoga K, Pengaruh Persepsi Harga dan Promosi terhadap Keputusan Pembelian Konsumen Produk Enervon-C, Jurnal Ilmiah dan Bisnis, Volume 1, Nomor 3, November 2015. Jurnal Online diakses pada Tanggal 6 Juni 2021

Doharma Tetty Damanik, Pengaruh Segmentasi Pasar, Bauran Pemasaran Terhadap Keputusan Pembelian Melalui Penggunaan Perangkat Komunikasi Sebagai Variable Intervening Pada Rumah Makan Tradisional Batak Umumnya Khususnya Pokkalan Nabolon Pematang Siantar, Magister Ilmu Manajemen Fakultas Ekonomi Dan Bisnis Universitas Sumatera Utara 2017, jurnal online diakses pada tanggal 7 Juni 2021

Istianah, Kholil Nawawi dan Syarifah Gustiawati, Analisis Sharia Marketing Mix Terhadap Kepercayaan Pelanggan dan Keputuasan Pembelian pada Online Shop Tiws.id , Jurnal Ekonomi Syariah Volume 5 Nomor 1 Tahun 2018

Imam Heryanto, Analisis Pengaruh Produk, Harga, Distribusi, dan Promosi terhadap Keputusan Pembelian serta Implikasinya pada Kepuasan Pelanggan, 2015, JEBE, Volume. 9, Nomor. 2. Jurnal Online diakses pada tanggal 9 Juni 2021

M. Rhendria Dinawan, Analisis Faktor - Faktor Yang Mempengaruhi Keputusan Pembelian(Studi Kasus Pada Konsumen Yamaha Mio Pt Harpindo Jaya Semarang), Mahasiswa Program Sarjana (S2) Program Studi Magister Manajemen Universitas Diponegoro, 2010. Jurnal Online diakses pada Tanggal 6 Juni 2021

Novelia Al-Raafi Rizki Adinda Sutrisno, Joko Widodo, Mukhamad Zulianto, Pengaruh Bauran Pemasaran Terhadap Keputusan Pembelian Produk RM Ayam Bakar Wong Solo Jember, Jurnal Ilmiah Ilmu Pendidikan, Ilmu Ekonomi, dan Ilmu Sosial, Volume 12 Nomor 2 (2018), Jurnal Online diakses pada Tanggal 8 Juni 2021

Rahmayanti Rivai, Pengaruh Bauran Pemasaran terhadap Keputusan Pembelian Kartu pada Mahasiswa Program Pascasarjana Universitas Tadulako, Mahasiswi Pascasarjana Universitas Tadulako 2019, jurnal Online diakses pada tanggal 8 Juni 2021

Rika Paujiah, Ahmad Mulyadi Kosim, Syarifah Gustiawati, Pengaruh Bauran Pemasaran Syariah dan Label Halal terhadap Keputusan Pembelian, Al Maal : Journal of Islamic Economics and Banking, E-ISSN : 580 - 3816, Volume : No 1 Vol 2 Bulan Januari Tahun 2020, Jurnal Online diakses pada tanggal 7 Juni 2021 
Samir Abuznaid, Islamic Marketing : Addessing The Muslim Market, Journal AnNajah Univ.J.Res (humanities), Vol. 26, 2012.

Sudirman, Syamsul Bachri dan Elimawaty Rombe, Pengaruh Bauran Pemasaran Terhadap Keputusan Pembelian City Car Kiapicanto Pada Pt. Kars Inti Amanah, (Kalla Kia) Palu, e-Jurnal Katalogis, Volume 3 Nomor 12, Desember 2015. Jurnal online diakses pada Tanggal 7 Juni 2021.

Solahuddin, Pengaruh Bauran Pemasaran Syari'ah Terhadap Keputusan Pembelian Perumahan Di Kota Pekanbaru, Mahasiswa Pascasarjana, UIN SUSKA RIAU 2020, . Jurnal Online diakses pada Tanggal 6 Juni 2021

Tyas, Ari Prasetyo, Pengaruh Bauran Pemasaran Terhadap Niat Menjadi Mitra Perspektif Islam pada BMT Beringharjo Cabang Madiun 2014., JESTT, Volume. 1 No. 7, Jurnal Online diakses pada tanggal 9 Juni 2021

Wini Bin Garib, S. L. H. V. Joyce Lapian, dan Lisbeth Mananeke, Pengaruh Bauran Promosi, Persepsi Harga dan Kualitas Produk terhadap Keputusan Pembelian Sepeda Motor Yamaha pada PT. Hasjrat Abadi Sentral Yamaha Malalayang, Jurnal WMBA, Vol. 7 No. 1 Januari 2019. Jurnal online diakses pada tanggal 6 Juni 2021

\section{Buku:}

Iqbal Hasan, 2004, Analisis Data Penelitian Dengan Statistik, (Jakarta : Bumi Aksara.

Iqbal Hasan, 2002, Pokok-pokok Materi Metodologi Penelitian dan Aplikasinya, (Jakarta: Ghalia Indonesia.

Suwartono, 2014, Dasar-dasar Metodologi Penelitian, Yogyakarta : Andi.

Zainal Abidin Mohd, 1992, Pengurusan pemasaran, (Kuala Lumpur: Dewan Bahasa).

Hermawan Kertajaya \& Muhammad Syakir Sula, 2006, Syariah Marketing, (Bandung: PT. Mizan). 